\title{
Fixed airways obstruction among patients with severe asthma: findings from the Singapore General Hospital-Severe Asthma Phenotype Study
}

Anthony Chau Ang Yii, Gan Liang Tan, Keng Leong Tan, Therese Sophie Lapperre and Mariko Siyue Koh*

\begin{abstract}
Background: A subset of severe asthma patients has fixed airways obstruction, which is characterized by incomplete reversibility to bronchodilator challenge. We aimed to elucidate the factors associated with fixed airways obstruction in a cohort of patients with severe asthma in Singapore.
\end{abstract}

Methods: 245 patients from the Singapore General Hospital-Severe Asthma Phenotype Study (SGH-SAPS) were screened. These patients fulfilled World Health Organization criteria for "treatment-resistant severe asthma" and were all on combination of high-dose inhaled corticosteroids and long-acting beta2 agonists. 76 patients had pre- and postbronchodilator lung function tests and were selected for analysis. They were divided into two groups based on postbronchodilator (Post BD) forced expiratory volume in one second, PostBDFEV $1 \%$ predicted: $\geq 70 \%$ (Non-Fixed Obs) and $<70 \%$ (Fixed Obs). We compared clinical and demographic parameters between the two groups.

Results: Patients in the Fixed Obs group were more frequently past or current smokers and had a higher pack-year smoking history. Overall, pack-year smoking history had a modest negative correlation with PostBDFEV ${ }_{1} \%$ predicted. Atopy, allergen sensitization (type and numbers), comorbidities, symptoms, health care utilization and medication use did not differ between the two groups. The prebronchodilator $\mathrm{FEV}_{1} \%$ predicted, $\mathrm{FEV} / \mathrm{FVC}$ and FVC \% predicted were significantly lower in the Fixed Obs group. In addition, prebronchodilator FVC \% predicted accounted for more variability than $\mathrm{FEV}_{1} / \mathrm{FVC}$ in predicting PostBDFEV $\mathrm{F}_{1} \%$ predicted.

Conclusion: Smoking is associated with fixed airways obstruction in patients with treatment-resistant severe asthma in Singapore. Furthermore, our results suggest that both small and large airways obstruction contribute independently to fixed airways obstruction in severe asthma.

Keywords: Fixed airways obstruction, Severe asthma, Smoking, Air trapping

\section{Background}

Asthma affects an estimated 315 million adults worldwide [1] and incurs substantial health care and socioeconomic costs [2]. Only $5 \%$ of all asthmatics have severe asthma, but they disproportionately account for most of the morbidity, mortality and health care burden across all asthma patients [3].

Even among those with severe disease, asthma is heterogeneous and consists of multiple phenotypes [4]. The fixed airways obstruction phenotype occurs in a small proportion

\footnotetext{
*Correspondence: mariko.koh.s.y@sgh.com.sg

Department of Respiratory and Critical Care Medicine, Singapore General Hospital, 20 College Road, Singapore 169856, Singapore
}

of patients who experience irreversible airways obstruction despite inhaled corticosteroids or bronchodilators [5,6]. Fixed airways obstruction in asthma is associated with more frequent exacerbations [7], increased asthma-related mortality [8] and overall mortality [9]. The causes of fixed obstruction in asthma are unknown but may be related to the presence of airway wall remodeling, which is characterized by increased airway smooth muscle mass and airway wall fibrosis [10].

Studies in American [11], European [12-15], Canadian [16] and East Asian $[17,18]$ cohorts have identified diverse but sometimes conflicting risk factors for fixed airways obstruction in asthma, including male sex, older age, longer 
duration of illness, smoking, eosinophilic airway inflammation, atopy and increased airway hyper-responsiveness. These inconsistent results could reflect differences in study methodologies, or the influence of gene-environment factors. We sought to elucidate the factors associated with fixed airways obstruction in Singaporean patients with severe asthma. To our knowledge, this is the first report to characterize fixed airways obstruction among asthmatics in a Southeast Asian cohort.

\section{Methods}

\section{Patient characteristics}

We interrogated the Singapore General Hospital-Severe Asthma Phenotype Study (SGH-SAPS) database, which consisted of 245 patients with severe asthma who presented to the Allergy or Respiratory clinics at Singapore General Hospital between 1 January 2011 and 31 December 2012. The diagnosis of asthma was made on the basis of history of episodic wheeze and dyspnea, clinical examination and supported by spirometry where indicated (reversibility of forced expiratory volume in one second $\left(\mathrm{FEV}_{1}\right)$ of $>12 \%$ and $200 \mathrm{ml}$, or demonstration of bronchial hyper-responsiveness with a positive methacholine challenge test, or $\mathrm{FEV}_{1}$ variability of $>15 \%$ ). Diagnosis of asthma was made by experienced clinicians in the field of respiratory and allergy in our hospital. Severe asthma was defined according to the World Health Organization classification of "treatment-resistant severe asthma" [19], that is, patients who require a combination of high-dose inhaled corticosteroids and long-acting beta agonists. Patients were considered to have treatment-resistant severe asthma based on the above criteria and following a period of treatment optimization, assessment of adherence, and identification and treatment of other comorbidities. The institution's ethics committee approved the study and waived the requirement for informed consent.

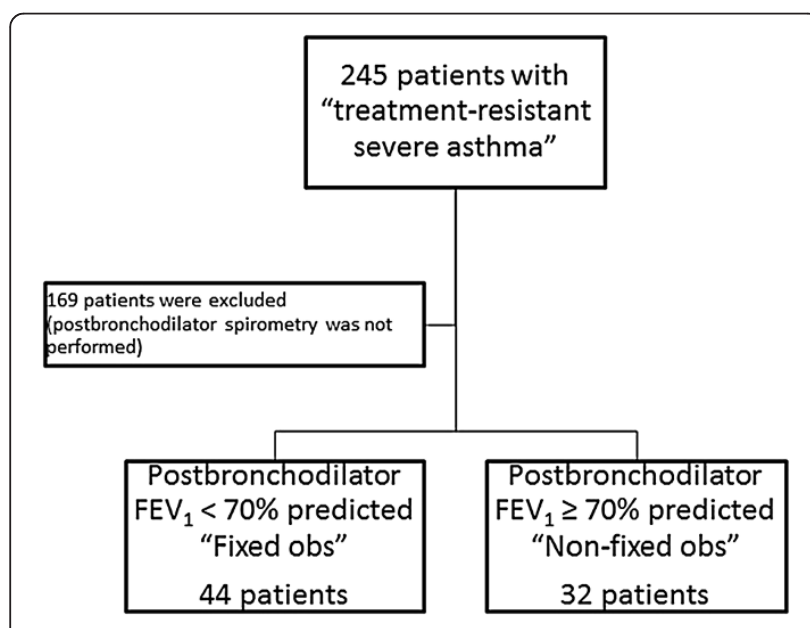

Figure 1 Study participants.
For the present analysis, we included 76 of the 245 patients (Figure 1) for whom postbronchodilator spirometry data were available and divided them into two groups based on postbronchodilator $\mathrm{FEV}_{1} \%$ predicted: $<70 \%$ ("Fixed Obs", $\mathrm{n}=44$ ) and $\geq 70 \%$ ("Non-fixed Obs", $\mathrm{n}=32$ ).

\section{Design}

This was a retrospective cross-sectional study.

\section{Measurements and investigations}

Asthma symptoms were evaluated using the Asthma Control Test [20]. We assessed for the presence of asthmarelated comorbidities of interest (allergic rhinitis, eczema, reflux, obstructive sleep apnea, anxiety, depression, aspirin sensitivity and vocal cord dysfunction) by obtaining history and reviewing medical records. The number of admissions, emergency visits, steroid bursts and medications over a two year period (2011-2012) were determined by questioning patients and cross-checking the national network of electronic health records, which contains discharge summaries, investigation results, emergency department records and electronic prescriptions from all public hospitals in Singapore.

Patient medications were coded according to an ordinal scale as follows: $1=$ inhaled corticosteroid only, $2=$ combination inhaled corticosteroid and beta-agonist (Combi), $3=$ Combi + theophylline, $4=$ Combi + leukotriene receptor antagonist (LTRA), $5=\mathrm{Combi}+$ Theophylline + LTRA, $6=$ Long term steroids, $7=$ Omalizumab, $8=$ Anticholinergic, $9=$ All of the above.

Spirometry was performed according to American Thoracic Society/European Respiratory Society guidelines [21], using a Medgraphics, USA spirometer. Predicted values were obtained from Morris et al. [22] and an adjustment factor of 0.94 was applied for $\mathrm{FEV}_{1}$ and forced vital capacity (FVC) as recommended for Asian patients [23]. Reversibility in $\mathrm{FEV}_{1}$ was measured 10 to 15 minutes after administration of $400 \mu \mathrm{g}$ inhaled salbutamol with a spacer, and was expressed as change in percentage predicted and absolute change in mls.

Skin prick tests were also retrospectively assessed and were performed with a panel (Stallergenes, France) which included the following extracts: dust mites (Bloomia tropicalis, Dermatophagoides pteronyssinus and farinae), dog and cat danders, feathers, cockroach, and molds (Aspergillus fumigatus), a negative control (glycerine) and positive control (histamine, $10 \mathrm{mg} / \mathrm{ml}$ ). A positive response was defined as any wheal with a diameter $3 \mathrm{~mm}$ greater than the negative control, 15 minutes after application.

\section{Statistical analysis}

Data were expressed either as mean \pm standard deviation (SD) for normally distributed continuous variables or alternatively as median (interquartile range) for ordinal 
variables and for non-normally distributed continuous variables. Comparisons between groups were performed using the Student's t-test for normally distributed continuous variables, the Mann-Whitney U test for ordinal and for non-normally distributed continuous variables, or the Chi-squared test for proportional data, as appropriate. Correlations were investigated using either the Spearman or Pearson tests. Hierarchical multiple linear regression was used to assess the relationship between prebronchodilator $\mathrm{FEV}_{1}$ and $\mathrm{FEV}_{1} / \mathrm{FVC}$ with PostBDFEV $V_{1}$. All variables found to be significant correlated with postbronchodilator $\mathrm{FEV}_{1}$ were evaluated for collinearity using a cut-off of tolerance $<0.2$ or variable inflation factor $>5$. Only predictor variables found to be non-collinear were included in multiple linear regression analysis employing the Automatic Linear Modelling module in SPSS version 20. Statistical procedures were carried out with IBM SPSS version 20. P values of less than 0.05 were considered significant.

\section{Results}

\section{Patient demographics}

The characteristics of the SGH-SAPS cohort are reported in Table 1. The distribution of ethnicity among the cohort as compared to the general population in Singapore was as follows: Chinese $(66.5 \%$ vs. $76.8 \%)$, Malay $(12.2 \%$ vs. $13.9 \%)$, Indian ( $15.1 \%$ vs. $7.9 \%)$, others (6.1\% vs. $1.4 \%)$. Overall, 44 patients (18\%) out of our cohort of 245 severe asthmatics had evidence of fixed airways obstruction, according to the definition of postbronchodilator $\mathrm{FEV}_{1}<$ $70 \%$ predicted. Among the 76 patients with bronchodilator testing, the mean age was $54.4 \pm 18.2$ years, the mean age of onset was $35.5 \pm 22.6$ years. Age, age of onset, duration of asthma, sex and body mass index were not different between the Fixed Obs and Non-Fixed Obs groups (Table 2). The mean and 95\% confidence interval (CI) for age and age of onset for the Fixed Obs group were $52.3 \mathrm{yrs} \pm 18.1$ (95\% CI: $46.8-57.8 \mathrm{yrs}$ ) and $32.8 \pm 22.9$ yrs (95\% CI: $25.8-39.8$ yrs), respectively.

\section{Smoking}

Table 2 and Figure 2 show the smoking history of subjects according to PostBDFEV 1 \% predicted. The proportion of current or past smokers was significantly higher for the Fixed Obs group compared to the Non-Fixed Obs group $(p=0.034)$. The former group also had a significantly higher pack-year history than the latter $(\mathrm{p}=0.022)$. In addition, there was a significant negative correlation between pack-year smoking history and PostBDFEV $\mathrm{B}_{1} \%$ predicted $\left(\mathrm{p}=0.004, \mathrm{r}_{\mathrm{s}}=-0.306\right)$ with pack-year smoking history accounting for approximately $9 \%$ of variability in PostBDFEV $_{1} \%$ predicted (Figure 3).

\section{Atopy, allergy tests and comorbidities}

The prevalence of atopic diseases (allergic rhinitis, aspirin sensitivity, eczema), allergen sensitization based on skin prick tests, prevalence of other asthma-related comorbidities such as gastroesophageal reflux, obstructive sleep apnea, vocal cord dysfunction, anxiety and depression were not different between the Fixed Obs and Non-Fixed Obs groups (Table 2).

\section{Symptoms, psychological dysfunction, health care utilization and medications}

Symptom control as measured by the Asthma Control Test was not different between groups. In addition, there were no between-group differences in terms of emergency visits, hospital admissions, near-fatal attacks, number of short courses of oral steroids in the past year, and asthma medication regimen.

Table 1 Baseline characteristics of the Singapore General Hospital-Severe Asthma Phenotype Study cohort

\begin{tabular}{|c|c|c|c|}
\hline & Overall cohort & Study participants & P-value (participants vs. non-participants) \\
\hline Patients (n) & 245 & 76 & \\
\hline Age (years) & $53.1 \pm 19.0$ & $54.4 \pm 18.2$ & NS \\
\hline Age of asthma onset (years) & $32.2 \pm 21.5$ & $35.5 \pm 22.6$ & NS \\
\hline Duration of asthma (years) & $20.9 \pm 16.7$ & $18.9 \pm 15.9$ & NS \\
\hline Gender (\% Males) & 47.3 & 50 & NS \\
\hline Ethnicity (\%) & & & NS \\
\hline Chinese & 66.5 & 65.8 & \\
\hline Malay & 12.2 & 10.5 & \\
\hline Indian & 15.1 & 18.4 & \\
\hline Others & 6.1 & 5.3 & \\
\hline Current or past smokers (\%) & 21.6 & 28.9 & NS \\
\hline Smoking history (pack-years) & 0 (0-0) Range 0-64 & 0 (0-1) Range 0-64 & NS \\
\hline Prebronchodilator FEV 1 \% (predicted) & $72.2 \pm 22.5$ & $54.9 \pm 17.2$ & $<0.001$ \\
\hline
\end{tabular}

Data is presented as mean $\pm \mathrm{SD}$, proportion or median (interquartile range). $\mathrm{FEV}_{1}=$ forced expiratory volume in one second, $\mathrm{NS}=$ not significant. 
Table 2 Comparisons between subjects with fixed and non-fixed airways obstruction

\begin{tabular}{|c|c|c|c|}
\hline Characteristic & $<70 \%$ (“Fixed Obs) & $\geq 70 \%$ (“Non-Fixed Obs") & $\mathrm{p}$-value \\
\hline Patients (n) & 44 & 32 & \\
\hline Age (years) & $52.3 \pm 18.1$ & $57.4 \pm 18.2$ & NS \\
\hline Age of asthma onset (years) & $32.8 \pm 22.9$ & $39.3 \pm 21.9$ & NS \\
\hline Before 12 years old (\%) & 34.1 & 18.8 & NS \\
\hline Before 18 years old (\%) & 36.4 & 18.8 & NS \\
\hline Before 40 years old (\%) & 50.0 & 50.0 & NS \\
\hline Duration of asthma (years) & $19.5 \pm 17.6$ & $18.1 \pm 13.5$ & NS \\
\hline Gender (\% Males) & 56.8 & 40.6 & NS \\
\hline Body mass index $\left(\mathrm{kg} / \mathrm{m}^{2}\right)$ & $25.2 \pm 7.3$ & $25.0 \pm 5.5$ & NS \\
\hline \multicolumn{4}{|l|}{ Serum eosinophils } \\
\hline No. of patients (n) & 43 & 31 & \\
\hline Absolute eosinophil count $\left(\times 10^{9} / \mathrm{L}\right)$ & $0.49 \pm 0.73$ & $0.46 \pm 0.43$ & NS \\
\hline Eosinophil count $\geq 0.4 \times 10^{9} / \mathrm{L}(\%)$ & 37.2 & 51.6 & NS \\
\hline \multicolumn{4}{|l|}{ Smoking } \\
\hline Current or past smokers (\%) & 38.6 & 15.6 & 0.029 \\
\hline \multirow[t]{2}{*}{ Smoking history (pack-years) } & $0(0-10)$ & $0(0-0)$ & 0.019 \\
\hline & Range: 0-64 & Range: 0-30 & \\
\hline \multicolumn{4}{|l|}{ Comorbidities } \\
\hline Allergic Rhinitis (\%) & 45.5 & 53.1 & NS \\
\hline Eczema (\%) & 100 & 100 & NS \\
\hline Gastroesophageal reflux disease (\%) & 15.9 & 12.5 & NS \\
\hline Obstructive sleep apnea (\%) & 6.8 & 0 & NS \\
\hline Anxiety (\%) & 6.8 & 0 & NS \\
\hline Depression (\%) & 2.3 & 3.1 & NS \\
\hline Aspirin sensitivity (\%) & 0.0 & 3.1 & NS \\
\hline Vocal cord dysfunction (\%) & 2.3 & 0 & NS \\
\hline
\end{tabular}

\section{Skin prick tests}

No. of patients (n)

Positive results on skin prick test to:

Blomia tropicalis (\%)

Dermatophagoides pteronyssinus (\%)

Dermatophagoides farinae (\%)

Dog (\%)

50.0

Cat (\%)

Feathers (\%)

21.4

Cockroach (\%)

Aspergillus (\%)

14.3

No. of allergens which test positive

$5(2.75-6)$

7.1

$4(3-5.25)$

Symptoms, health care use, medications

Asthma Control Test score

Admissions in the past 2 years

$\%$ admitted in past 2 years

Emergency visits in the past 2 years

$\%$ with emergency visits in past 2 years
$20(16-22)$

$0(0-0)(n=42)$

14.3

$0(0-2)(n=43)$

48.8
$20(19-24)$

NS

$0(0-2)(n=31) \quad$ NS

32.3

NS

$1(0-2)(n=31)$

NS

58.1 
Table 2 Comparisons between subjects with fixed and non-fixed airways obstruction (Continued)

\begin{tabular}{|c|c|c|c|}
\hline No. of steroid bursts in the past year & $1(0-2)$ & $1(0-2)$ & NS \\
\hline$\%$ with steroid bursts in the past year & 61.4 & 71.9 & NS \\
\hline History of near-fatal asthma (\%) & 4.5 & 9.4 & NS \\
\hline Medication regimen & $2(2-4)$ & $2(2-4)$ & NS \\
\hline \multicolumn{4}{|l|}{ Lung function } \\
\hline \multicolumn{4}{|l|}{ PostBDFEV $_{1}$ (\% predicted) } \\
\hline Range & $32-69$ & $71-123$ & NA \\
\hline Prebronchodilator FEV $1 \%$ predicted) & $45.1 \pm 10.0$ & $68.4 \pm 15.9$ & $<0.001$ \\
\hline Prebronchodilator FVC (\% predicted) & $56.8 \pm 16.8$ & $74.6 \pm 15.1$ & $<0.001$ \\
\hline Prebronchodilator $\mathrm{FEV}_{1} / \mathrm{FVC}(\%)$ & $61.3 \pm 14.1$ & $70.9 \pm 12.0$ & 0.003 \\
\hline Percentage reversibility in $\mathrm{FEV}_{1}(\%)$ & $26.8 \pm 24.2$ & $25.9 \pm 18.6$ & NS \\
\hline Reversibility in $\mathrm{FEV}_{1}(\mathrm{ml})$ & $283 \pm 222$ & $360 \pm 242$ & NS \\
\hline
\end{tabular}

Data is presented as mean $\pm \mathrm{SD}$, proportion or median (interquartile range)

$\mathrm{FEV}_{1}=$ forced expiratory volume in one second, $\mathrm{FVC}=$ forced vital capacity, NS = not significant, NA= not applicable. Medication regimen is expressed as an ordinal scale as follows: $1=$ inhaled corticosteroid only, $2=$ combination inhaled corticosteroid and beta-agonist $($ Combi), $3=$ Combi + theophylline, $4=$ Combi + receptor antagonist (LTRA), $5=$ Combi + Theophylline + LTRA, $6=$ Long term steroids, $7=$ Omalizumab, $8=$ Anticholinergic, $9=$ All of the above.

\section{Lung function}

The prebronchodilator $\mathrm{FEV}_{1} \%$ predicted, $\mathrm{FEV}_{1} / \mathrm{FVC}$ and FVC \% predicted were significantly lower in the Fixed Obs group compared to the Non-Fixed Obs group.

\section{Correlational analysis}

Bivariate analyses of the entire study sample $(n=76)$ demonstrated that postbronchodilator $\mathrm{FEV}_{1} \%$ predicted was significantly correlated with the following continuous or ordinal variables (Table 3): pack-year smoking history, prebronchodilator $\mathrm{FEV}_{1}, \mathrm{FVC}$, and $\mathrm{FEV}_{1} / \mathrm{FVC}$,

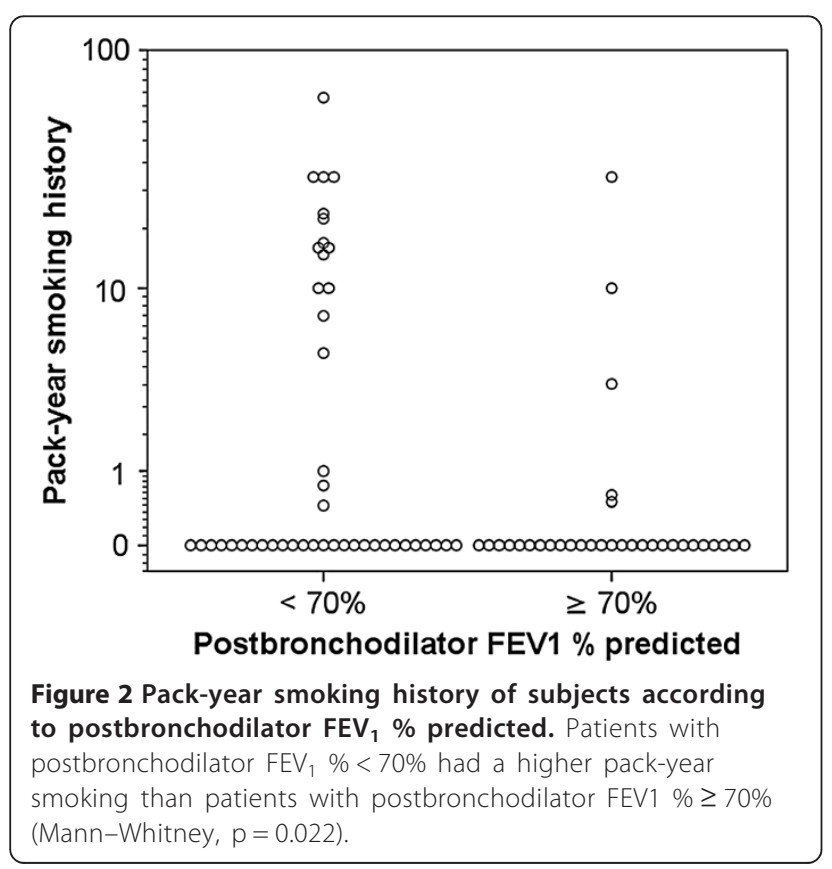

and admissions in the past year. Collinearity diagnostics revealed that among all the significantly correlated variables, prebronchodilator $\mathrm{FEV}_{1}$ had a high degree of multicollinearity (tolerance $=0.175$, variable inflation factor $=$ 5.717), hence it was removed from the final multiple linear regression model. Multivariate regression incorporating all other variables found to be significantly correlated with postbronchodilator $\mathrm{FEV}_{1} \%$ predicted (Table 4) showed that the following variables were significantly and independently associated with postbronchodilator $\mathrm{FEV}_{1}$, in order of decreasing importance: prebronchodilator FVC \% predicted, prebronchodilator $\mathrm{FEV}_{1} / \mathrm{FVC}$ and smoking.

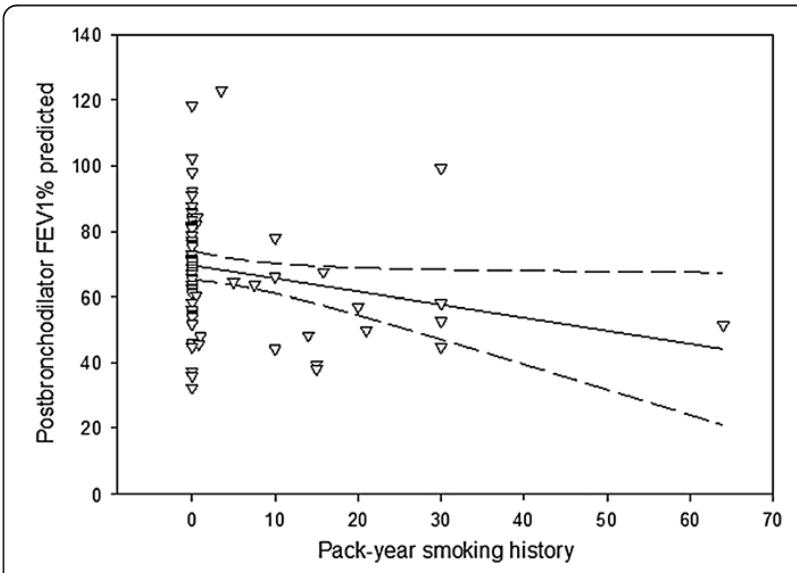

Figure 3 The relationship between postbronchodilator forced expiratory volume in one second \% predicted versus pack-year smoking history. Solid and dashed lines denote the fitted linear regression curve and 95\% confidence interval, respectively. 
Table 3 Variables correlated with postbronchodilator forced expiratory volume in one second \% predicted

\begin{tabular}{lll}
\hline Variable & Correlation coefficient & p-value \\
\hline Age (years) & $0.203^{\#}$ & 0.08 \\
Age of onset (years) & $0.200^{\#}$ & 0.09 \\
Duration of asthma (years) & $-0.056^{\#}$ & 0.63 \\
Body mass index $\left(\mathrm{kg} / \mathrm{m}^{2}\right)$ & $0.029^{\#}$ & 0.80 \\
Serum eosinophils $\left(\times 10^{9} / \mathrm{L}\right)$ & $-0.092^{\#}$ & 0.43 \\
Pack-year smoking history & $-0.306^{*}$ & 0.007 \\
Asthma control test score & $0.143^{*}$ & 0.22 \\
No. of emergency visits in past two years & $0.102^{*}$ & 0.39 \\
Steroid bursts in the past year & $0.102^{*}$ & 0.38 \\
Medication regimen & $0.014^{*}$ & 0.90 \\
Admissions in the past year & $0.278^{*}$ & 0.015 \\
Prebronchodilator FEV $1 \%$ predicted) & $0.882^{\#}$ & $<0.001$ \\
Prebronchodilator FVC (\% predicted) & $0.650^{\#}$ & $<0.001$ \\
Prebronchodilator FEV $/$ FVC (\%) & $0.425^{\#}$ & $<0.001$ \\
Reversibility (\%) & $0.012^{\#}$ & 0.92 \\
Reversibility (ml) & $0.163^{\#}$ & 0.16 \\
\hline
\end{tabular}

Medication regimen is expressed as an ordinal scale as follows: $1=$ inhaled corticosteroid only, $2=$ combination inhaled corticosteroid and beta-agonist (Combi), $3=$ Combi + theophylline, $4=$ Combi + leukotriene receptor antagonist (LTRA), $5=$ Combi + Theophylline + LTRA, $6=$ Long term steroids, $7=$ Omalizumab, $8=$ Anticholinergic, $9=$ All of the above.

\#Pearson coefficients, *Spearmann coefficients. FEV $1=$ forced expiratory volume in one second, FVC = forced vital capacity.

Relative importance of prebronchodilator $\mathrm{FEV}_{1} / \mathrm{FVC}$ and FVC \% predicted in predicting bronchodilator reversibility Both prebronchodilator $\mathrm{FEV}_{1} / \mathrm{FVC}$ and $\mathrm{FVC} \%$ predicted had a positive correlation with postbronchodilator $\mathrm{FEV}_{1} \%$ predicted (Figure 4 ). In order to discern the relative importance of $\mathrm{FEV}_{1} / \mathrm{FVC}$ and $\mathrm{FVC} \%$ predicted in contributing to the variance of postbronchodilator $\mathrm{FEV}_{1}$, a hierarchical multiple regression was performed. Entering $\mathrm{FEV}_{1} / \mathrm{FVC}$ first led to a model with $\mathrm{R}^{2}=0.175, \mathrm{p}<0.001$. Subsequently, entering FVC \% predicted into the model led to a change in $\mathrm{R}^{2}$ of $0.508, \mathrm{p}<0.001$, to a final $\mathrm{R}^{2}$ of 0.683 . The combined model incorporating both $\mathrm{FEV}_{1} / \mathrm{FVC}$ and FVC \% predicted had standardized beta coefficients of $0.517(\mathrm{p}<0.001)$ and $0.720(\mathrm{p}<0.001)$ respectively.

\section{Discussion}

We aimed to elucidate the factors associated with fixed airways obstruction in a cohort of patients with severe asthma in Singapore. Smoking was found to be associated

Table 4 Multiple linear regression of factors correlated with postbronchodilator FEV $_{\mathbf{1}} \%$ predicted

\begin{tabular}{lccc}
\hline Factor & Coefficient & p-value & Importance \\
\hline $\begin{array}{l}\text { Prebronchodilator FVC } \\
\text { (\% predicted) }\end{array}$ & 0.709 & $<0.001$ & 0.666 \\
Prebronchodilator (FEV 1 FVC \%) & 0.606 & $<0.001$ & 0.294 \\
Pack-year smoking history & -0.293 & 0.049 & 0.024 \\
Admissions in the past year & -4.921 & NS & 0.016 \\
\hline
\end{tabular}

with fixed airways obstruction. Pack-year smoking history correlated modestly with the degree of fixed airways obstruction. There were also important differences in lung function in asthma patients with fixed airways obstruction. Those with fixed airways obstruction manifested with lower prebronchodilator $\mathrm{FEV}_{1} \%$ predicted, FVC \% predicted and $\mathrm{FEV}_{1} / \mathrm{FVC}$. FVC was found to account for more variability than $\mathrm{FEV}_{1} / \mathrm{FVC}$ in predicting postbronchodilator $\mathrm{FEV}_{1} \%$ predicted. These results suggest that both small and large airways obstruction contribute independently to fixed airways obstruction in severe asthma.

Our findings are consistent with previous reports of an association between smoking and fixed airways obstruction in severe asthmatics (the TENOR [11] and COREA [17] studies), which reported prevalences of fixed airways obstruction at $60 \%$ and $51 \%$ respectively. In both these studies, smoking was a significant factor associated with fixed airways obstruction and both studies had relatively high smoking rates among their patients (47\% in TENOR and 56\% in COREA). In comparison, only $18 \%$ of our cohort of 245 patients had fixed airways obstruction and our smoking rates (22\%) among the Fixed Obs and Non-Fixed Obs groups are lower than the two studies, yet we found a significant association between smoking and fixed airways obstruction. We were also able to demonstrate this association despite our subjects having a lower pack-year history when compared with the COREA study. Bumbacea et al. [12] reported a group of patients with PostBDFEV $1<50 \%$ predicted who had equivalent pack-year history to our subjects with PostBDFEV $_{1}<70 \%$ 

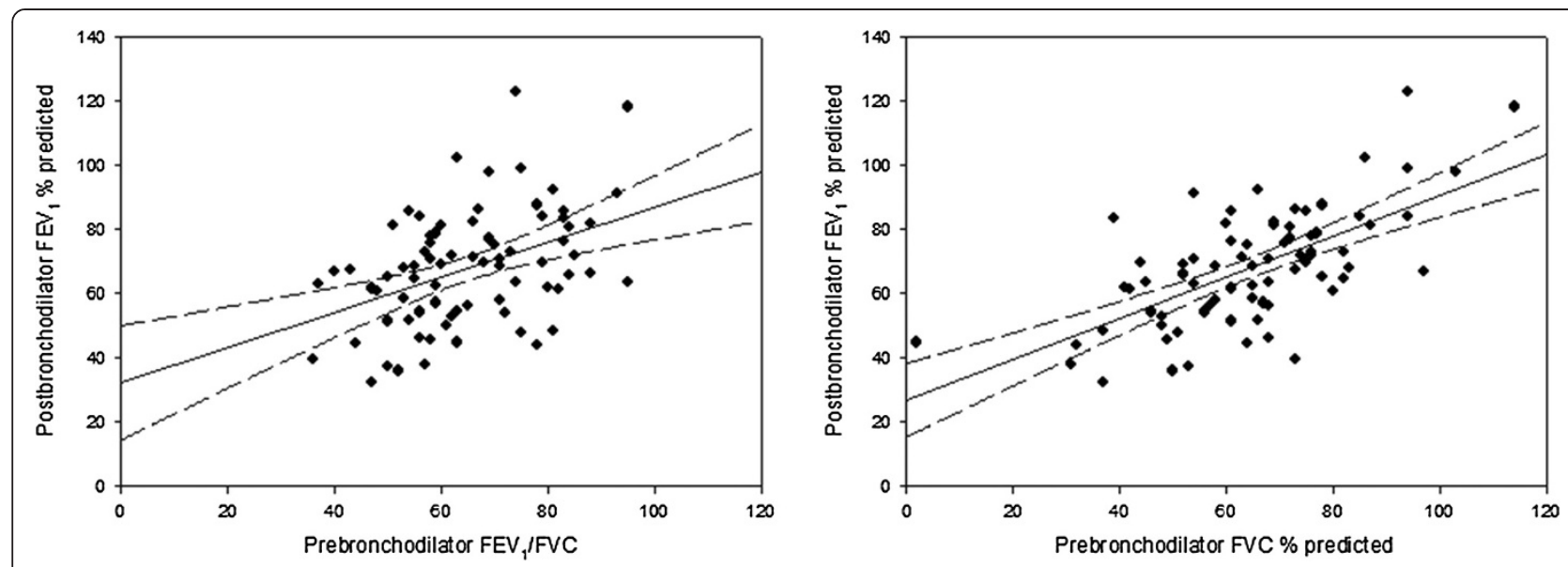

Figure 4 The relationship between prebronchodilator $\mathrm{FEV}_{1} / \mathrm{FVC}$ and FVC \% predicted with postbronchodilator FEV $1 \%$ predicted. Solid and dashed lines denote the fitted linear regression curve and $95 \%$ confidence interval, respectively.

predicted, but their study was unable to demonstrate an association of fixed obstruction with smoking. Notwithstanding differences in study methodology, this discrepancy may reflect gene-environment differences, where varying thresholds of amount smoked lead to the development of fixed obstruction. Similarly, significant reductions in FVC have been reported previously in asthmatics with severe irreversible airflow obstruction [12]. However, to our knowledge, this is the first study to report that FVC is a more important predictor than $\mathrm{FEV}_{1} / \mathrm{FVC}$ of the degree of fixed airways obstruction.

There are several possible caveats in this study. First, there was incomplete data on bronchodilator reversibility in our cohort. This partly reflects our institutional practice of performing methacholine challenge, a test of bronchial responsiveness, as an adjunct for diagnosing asthma when patients have normal $\mathrm{FEV}_{1}$. Second, the subjects with irreversible obstruction may have received a misdiagnosis of asthma when in fact they have chronic obstructive pulmonary disease (COPD). However, the average age of onset of symptoms in subjects with PostBDFEV $_{1}<70 \%$ was 32.8 years (95\% CI: 25.8-39.8 years), whereas the onset of symptoms in COPD occurs mostly after the age of 40 [24]. The average bronchodilator reversibility in the group with PostBDFEV $\mathrm{V}_{1}<70 \%$ was $26.8 \%$, whereas reversibility in COPD in less marked (less than $12-15 \%)$. Furthermore, asthma was diagnosed in our patients after careful clinical evaluation by experienced clinicians in the field of allergy and respiratory diseases. Previous work has shown that in patients with similar levels of fixed obstruction, history can distinguish asthma and COPD as separate airway pathologies $[25,26]$. Therefore, it is unlikely that we have inadvertently included subjects with COPD instead of asthma.

The third limitation is that the subjects in the present study who have fixed airways obstruction may belong to the asthma-COPD overlap syndrome. Overlap syndrome is recognized by coexistence of increased variability of airflow in a patient with incompletely reversible airways obstruction [27]. Patients with overlap syndrome are often excluded from clinical trials, and risk factors for the development and natural history of overlap syndrome are relatively unknown and unexplored. By definition, the difference between asthma with fixed obstruction and overlap syndrome is purely semantic and we are therefore unable to exclude that our patients have overlap syndrome. Yet, the major implication of overlap syndrome is that asthma and COPD are actually different manifestations of the same disease and share a common pathogenic origin where one condition may evolve into the other, referred to as the Dutch hypothesis [28]. The aim of the present study was not to evaluate the Dutch hypothesis, and our results do not support nor refute the Dutch hypothesis.

The most likely inference is that the subjects with PostBDFEV $_{1}<70 \%$ are asthma patients who have developed fixed obstruction in association with smoking. Our results are also in keeping with longitudinal studies showing accelerated lung function decline in asthma individuals who smoke compared to nonsmoking asthmatics $[29,30]$. The reasons for this are several fold [31]: smoking reduces corticosteroid sensitivity in asthmatics [32,33]; exposure to cigarette smoke enhances not only allergic Th2-driven inflammation [34], but also Th1mediated (neutrophilic) inflammatory responses [33] which are not normally responsive to corticosteroids; smoking causes impaired ciliary function [35] thus renders smokers more prone to upper and lower respiratory tract infections i.e. more variability than frequent exacerbations [36].

Our results also shed light on the underlying pathophysiological derangements associated with incomplete 
reversibility of $\mathrm{FEV}_{1}$ following bronchodilator challenge in asthma. $\mathrm{FEV}_{1}$ as a measure of obstruction may be partitioned into components of air trapping (indicated by FVC and reflecting small airways disease) and airflow limitation (indicated by $\mathrm{FEV}_{1} / \mathrm{FVC}$ and reflecting large airway luminal caliber) [37-40]. Asthma has traditionally been attributed to large airway pathology [41], but we found that FVC accounted for more variability than $\mathrm{FEV}_{1} / \mathrm{FVC}$ in predicting postbronchodilator $\mathrm{FEV}_{1}$, suggesting that small airways disease is at least as important as large airways disease in contributing to fixed airways obstruction. Our results resonate with an early study [42] localizing the site of obstruction to the small airways in asthmatics with fixed obstruction by analyzing the variation in maximum expiratory flow volume curves at different gas densities. More recently, air trapping as a radiological finding has been reported as a significant determinant of fixed obstruction in asthma $[39,43]$. Furthermore, air trapping and small airways disease is a unique feature of severe asthma that is absent in nonsevere asthma [44]. Preliminary studies show promising results of therapies targeting distal airways, such as ultrafine bronchodilators and inhaled corticosteroids [45] and leukotriene antagonists [46], but whether these treatments can avert the development of fixed obstruction remains to be elucidated.

Our study also underscores the importance of smoking cessation in asthma patients to mitigate the development of irreversible airways obstruction. Several anti-smoking strategies have been in place in Singapore since the 1970s, including mandatory graphic health warnings on tobacco products, prohibition of tobacco advertisements and promotion, heavy tobacco taxation and a ban on smoking in public places. Smoking prevalence in Singapore has declined from $20 \%$ in 1984 to $12.6 \%$ in 2004 , among the lowest rates in the world. Despite this, we are confronted with a fairly high prevalence of smoking in our cohort of severe asthmatics (22\%). This implies the need for intensified efforts to promote smoking cessation in asthma patients in order to harness the beneficial effects of smoking cessation on asthma such as improvements in symptoms and lung function [47].

\section{Conclusions}

Smoking is associated with fixed airways obstruction in patients with treatment-resistant severe asthma in Singapore. Our findings underscore the importance of smoking cessation in asthma patients to mitigate the development of irreversible airways obstruction. In addition, FVC \% predicted was found to account for more variability than $\mathrm{FEV}_{1} / \mathrm{FVC}$ in predicting postbronchodilator $\mathrm{FEV}_{1} \%$ predicted. These results suggest that both small and large airways disease contribute independently to fixed airways obstruction in severe asthma.

\section{Ethics approval}

This study was approved by the Singhealth Centralised Institutional Review Board. The approval number was CIRB 2010/810/C.

\section{Abbreviations}

SGH-SAPS: Singapore General Hospital-Severe Asthma Phenotype Study; $\mathrm{FEV}_{1}$ : Forced expiratory volume in one second; FVC: Forced vital capacity; PostBDFEV 1 : Postbronchodilator forced expiratory volume in one second; NA: Not applicable; NS: Not significant; SD: Standard deviation.

\section{Competing interests}

The authors declare that they have no competing interests.

\section{Authors' contributions}

ACAY contributed to the development of the study design, performed the statistical analysis and wrote the manuscript. GLT helped with the data analysis and manuscript preparation. KLT and TSL helped with manuscript preparation. MSK contributed to the development of the study design, collection of study data, data analysis, manuscript preparation and is guarantor for this study, including its data and analysis. All authors read and approved the final manuscript.

\section{Acknowledgements}

The authors appreciate the help from Ms Karen Tan and Ms Zeng Baoyi for data collection and Taara Madhavan for assistance with editing. This publication was supported in part by the Singapore General Hospital Centre Grant from the National Medical Research Council, Singapore (NMRC/CG/ 016/2013).

Received: 7 May 2014 Accepted: 27 November 2014

Published: 3 December 2014

\section{References}

1. To T, Stanojevic S, Moores G, Gershon AS, Bateman ED, Cruz AA, Boulet L-P: Global asthma prevalence in adults: findings from the cross-sectional world health survey. BMC Public Health 2012, 12:204.

2. Bousquet J, Bousquet PJ, Godard P, Daures J-P: The public health implications of asthma. Bull World Health Organ 2005, 83:548-554.

3. Masoli M, Fabian D, Holt S, Beasley R: The global burden of asthma: executive summary of the GINA Dissemination Committee report. Allergy 2004, 59:469-478.

4. Kiley J, Smith R, Noel P: Asthma phenotypes. Curr Opin Pulm Med 2007, 13:19-23.

5. Boulet LP, Turcotte $H$, Brochu A: Persistence of airway obstruction and hyperresponsiveness in subjects with asthma remission. Chest 1994, 105:1024-1031.

6. Brown PJ, Greville HW, Finucane KE: Asthma and irreversible airflow obstruction. Thorax 1984, 39:131-136.

7. Contoli M, Baraldo S, Marku B, Casolari P, Marwick JA, Turato G, Romagnoli M, Caramori G, Saetta M, Fabbri LM, Papi A: Fixed airflow obstruction due to asthma or chronic obstructive pulmonary disease: 5-year follow-up. J Allergy Clin Immunol 2010, 125:830-837.

8. Panizza JA, James AL, Ryan G, de Klerk N, Finucane KE: Mortality and airflow obstruction in asthma: a 17-year follow-up study. Intern Med J 2006, 36:773-780.

9. Hansen EF, Phanareth K, Laursen LC, Kok-Jensen A, Dirksen A: Reversible and irreversible airflow obstruction as predictor of overall mortality in asthma and chronic obstructive pulmonary disease. Am J Respir Crit Care Med 1999, 159(4 Pt 1):1267-1271.

10. James AL, Wenzel S: Clinical relevance of airway remodelling in airway diseases. Eur Respir J Off J Eur Soc Clin Respir Physiol 2007, 30:134-155.

11. Lee JH, Haselkorn T, Borish L, Rasouliyan L, Chipps BE, Wenzel SE: Risk factors associated with persistent airflow limitation in severe or difficult-to-treat asthma: insights from the TENOR study. Chest 2007, 132:1882-1889. 
12. Bumbacea D, Campbell D, Nguyen L, Carr D, Barnes PJ, Robinson D, Chung KF: Parameters associated with persistent airflow obstruction in chronic severe asthma. Eur Respir J Off J Eur Soc Clin Respir Physiol 2004, 24:122-128.

13. Vonk JM, Jongepier H, Panhuysen CIM, Schouten JP, Bleecker ER, Postma DS: Risk factors associated with the presence of irreversible airflow limitation and reduced transfer coefficient in patients with asthma after 26 years of follow up. Thorax 2003, 58:322-327.

14. Connolly CK, Chan NS, Prescott RJ: The relationship between age and duration of asthma and the presence of persistent obstruction in asthma. Postgrad Med J 1988, 64:422-425.

15. Ten Brinke A, Zwinderman AH, Sterk PJ, Rabe KF, Bel EH: Factors associated with persistent airflow limitation in severe asthma. Am J Respir Crit Care Med 2001, 164:744-748.

16. Hudon C, Turcotte H, Laviolette M, Carrier G, Boulet LP: Characteristics of bronchial asthma with incomplete reversibility of airflow obstruction. Ann Allergy Asthma Immunol 1997, 78:195-202.

17. Lee T, Lee YS, Bae Y-J, Kim T-B, Kim SO, Cho S-H, Moon H-B, Cho YS: Smoking, longer disease duration and absence of rhinosinusitis are related to fixed airway obstruction in Koreans with severe asthma: findings from the COREA study. Respir Res 2011, 12:1.

18. Jang A-S, Park J-S, Lee J-H, Park S-W, Kim D-J, Uh S-T, Kim Y-H, Park C-S Asthmatics without rhinitis have more fixed airway obstruction than those with concurrent rhinitis. Allergy Asthma Immunol Res 2010, 2:108-113.

19. Bousquet J, Mantzouranis E, Cruz AA, Aït-Khaled N, Baena-Cagnani CE, Bleecker ER, Brightling CE, Burney P, Bush A, Busse WW, Casale TB, ChanYeung M, Chen R, Chowdhury B, Chung KF, Dahl R, Drazen JM, Fabbri LM, Holgate ST, Kauffmann F, Haahtela T, Khaltaev N, Kiley JP, Masjedi MR, Mohammad Y, O'Byrne P, Partridge MR, Rabe KF, Togias A, van Weel C, Wenzel S, Zhong N, Zuberbier T: Uniform definition of asthma severity, control, and exacerbations: document presented for the World Health Organization Consultation on Severe Asthma. J Allergy Clin Immunol 2010, 126:926-938.

20. Nathan RA, Sorkness CA, Kosinski M, Schatz M, Li JT, Marcus P, Murray JJ, Pendergraft TB: Development of the asthma control test: a survey for assessing asthma control. J Allergy Clin Immunol 2004, 113:59-65.

21. Miller MR, Hankinson J, Brusasco V, Burgos F, Casaburi R, Coates A, Crapo R, Enright P, van der Grinten CPM, Gustafsson P, Jensen R, Johnson DC, MacIntyre N, McKay R, Navajas D, Pedersen OF, Pellegrino R, Viegi G, Wanger J: Standardisation of spirometry. Eur Respir J Off J Eur Soc Clin Respir Physiol 2005, 26:319-338.

22. Morris JF, Koski A, Johnson LC: Spirometric standards for healthy nonsmoking adults. Am Rev Respir Dis 1971, 103:57-67

23. Pellegrino R, Viegi G, Brusasco V, Crapo RO, Burgos F, Casaburi R, Coates A, van der Grinten CPM, Gustafsson P, Hankinson J, Jensen R, Johnson DC, Maclntyre N, McKay R, Miller MR, Navajas D, Pedersen OF, Wanger J: Interpretative strategies for lung function tests. Eur Respir J Off J Eur Soc Clin Respir Physiol 2005, 26:948-968.

24. Vestbo J, Hurd SS, Agustí AG, Jones PW, Vogelmeier C, Anzueto A, Barnes PJ, Fabbri LM, Martinez FJ, Nishimura M, Stockley RA, Sin DD, RodriguezRoisin R: Global Strategy for the Diagnosis, Management, and Prevention of Chronic Obstructive Pulmonary Disease: GOLD Executive Summary. Am J Respir Crit Care Med 2013, 187:347-365

25. Fabbri LM, Romagnoli M, Corbetta L, Casoni G, Busljetic K, Turato G, Ligabue G, Ciaccia A, Saetta M, Papi A: Differences in airway inflammation in patients with fixed airflow obstruction due to asthma or chronic obstructive pulmonary disease. Am J Respir Crit Care Med 2003, 167:418-424.

26. Di Lorenzo G, Mansueto P, Ditta V, Esposito-Pellitteri M, Lo Bianco C, Leto-Barone MS, D'Alcamo A, Farina C, Di Fede G, Gervasi F, Caruso C, Rini G: Similarity and differences in elderly patients with fixed airflow obstruction by asthma and by chronic obstructive pulmonary disease. Respir Med 2008, 102:232-238.

27. Gibson PG, Simpson JL: The overlap syndrome of asthma and COPD what are its features and how important is it? Thorax 2009, 64:728-735.

28. Sluiter HJ, Koëter GH, de Monchy JG, Postma DS, de Vries K, Orie NG: The Dutch hypothesis (chronic non-specific lung disease) revisited. Eur Respir J Off J Eur Soc Clin Respir Physiol 1991, 4:479-489.

29. Perret JL, Dharmage SC, Matheson MC, Johns DP, Gurrin LC, Burgess JA, Marrone J, Markos J, Morrison S, Feather I, Thomas PS, McDonald CF, Giles GG, Hopper JL, Wood-Baker R, Abramson MJ, Walters EH: The Interplay Between Lifetime Asthma, Smoking and Atopy on Fixed Airflow Obstruction in Middle-age. Am J Respir Crit Care Med 2012, 187(1):42-48.
30. Lange P, Parner J, Vestbo J, Schnohr P, Jensen G: A 15-year follow-up study of ventilatory function in adults with asthma. N Engl J Med 1998, 339:1194-1200.

31. Haughney J, Price D, Kaplan A, Chrystyn H, Horne R, May N, Moffat M, Versnel J, Shanahan ER, Hillyer EV, Tunsäter A, Bjermer L: Achieving asthma control in practice: understanding the reasons for poor control. Respir Med 2008, 102:1681-1693.

32. Thomson NC, Chaudhuri R, Livingston E: Asthma and cigarette smoking. Eur Respir J Off J Eur Soc Clin Respir Physiol 2004, 24:822-833.

33. Chalmers GW, Macleod KJ, Little SA, Thomson LJ, McSharry CP, Thomson $\mathrm{NC}$ : Influence of cigarette smoking on inhaled corticosteroid treatment in mild asthma. Thorax 2002, 57:226-230.

34. Van Hove CL, Moerloose K, Maes T, Joos GF, Tournoy KG: Cigarette smoke enhances Th-2 driven airway inflammation and delays inhalational tolerance. Respir Res 2008, 9:42.

35. Verra F, Escudier E, Lebargy F, Bernaudin JF, De Crémoux H, Bignon J: Ciliary abnormalities in bronchial epithelium of smokers, ex-smokers, and nonsmokers. Am J Respir Crit Care Med 1995, 151(3 Pt 1):630-634.

36. Patel SN, Tsai C-L, Boudreaux ED, Kilgannon JH, Sullivan AF, Blumenthal D, Camargo CA: Multicenter study of cigarette smoking among patients presenting to the emergency department with acute asthma. Ann Allergy Asthma Immunol 2009, 103:121-127.

37. Gibbons WJ, Sharma A, Lougheed D, Macklem PT: Detection of excessive bronchoconstriction in asthma. Am J Respir Crit Care Med 1996, 153:582-589.

38. Brown RH, Pearse DB, Pyrgos G, Liu MC, Togias A, Permutt S: The structural basis of airways hyperresponsiveness in asthma. J App/ Physio/ 2006, 101:30-39.

39. Ito R, Yokoyama A, Hamada H, Yasuhara Y, Kohno N, Higaki J: Effect of inhaled bronchodilators on air trapping in patients with stable asthma. J Asthma 2006, 43:125-129.

40. In 't Veen JC, Beekman AJ, Bel EH, Sterk PJ: Recurrent exacerbations in severe asthma are associated with enhanced airway closure during stable episodes. Am J Respir Crit Care Med 2000, 161:1902-1906.

41. Mead J: The lung's "quiet zone". N Engl J Med 1970, 282:1318-1319.

42. Despas PJ, Leroux M, Macklem PT: Site of airway obstruction in asthma as determined by measuring maximal expiratory flow breathing air and a helium-oxygen mixture. J Clin Invest 1972, 51:3235-3243.

43. Park S-W, Park J-S, Jeong SH, Lee YN, Hwangbo Y, Park JS, Lee JH, Jang A-S, Kim D-J, Uh ST, Kim YH, Park C-S: Air trapping is a major determinant of persistent airway obstruction in asthmatics. Respir Med 2012, 106:786-793.

44. Sorkness RL, Bleecker ER, Busse WW, Calhoun WJ, Castro M, Chung KF, Curran-Everett D, Erzurum SC, Gaston BM, Israel E, Jarjour NN, Moore WC, Peters SP, Teague WG, Wenzel SE: Lung function in adults with stable but severe asthma: air trapping and incomplete reversal of obstruction with bronchodilation. J Appl Physiol 2008, 104:394-403.

45. Burgel P-R, de Blic J, Chanez P, Delacourt C, Devillier P, Didier A, Dubus J-C, Frachon I, Garcia G, Humbert M, Laurent F, Louis R, Magnan A, Mahut B, Perez T, Roche N, Tillie-Leblond I, de Tunon Lara M, Dusser D: Update on the roles of distal airways in asthma. Eur Respir Rev 2009, 18:80-95.

46. Zeidler MR, Kleerup EC, Goldin JG, Kim HJ, Truong DA, Simmons MD, Sayre JW, Liu W, Elashoff R, Tashkin DP: Montelukast improves regional air-trapping due to small airways obstruction in asthma. Eur Respir J Off J Eur Soc Clin Respir Physiol 2006, 27:307-315.

47. Chaudhuri R, Livingston E, MCMahon AD, Lafferty J, Fraser I, Spears M, McSharry CP, Thomson NC: Effects of smoking cessation on lung function and airway inflammation in smokers with asthma. Am J Respir Crit Care Med 2006, 174:127-133.

doi:10.1186/1471-2466-14-191

Cite this article as: Yii et al:: Fixed airways obstruction among patients with severe asthma: findings from the Singapore General HospitalSevere Asthma Phenotype Study. BMC Pulmonary Medicine 2014 14:191. 